\title{
Przez wątrobę do serca. Aspekty praktyczne kardiomiopatii wątrobowej - przegląd piśmiennictwa
}

\author{
Liver pathology affecting the heart. Practical aspects \\ of cirrhotic cardiomyopathy - a literature review
}

\author{
Adam R. Markowski, Hanna Kamalska \\ Oddział Chorób Wewnętrznych i Gastroenterologii Samodzielnego Szpitala Miejskiego im. PCK w Białymstoku
}

\section{Streszczenie}

Kardiomiopatia wątrobowa jest zespołem zaburzeń funkcji serca, ze skurczową i rozkurczową dysfunkcją lewej komory oraz nieprawidłowościami elektrofizjologicznymi występującymi u osób z marskością wątroby, w przypadku braku innej, znanej przyczyny choroby serca, niezależnie od spożycia alkoholu. Zwykle ma przebieg subkliniczny, a jej objawy pojawiają się dopiero w warunkach stresu hemodynamicznego, na przykład dużego wysiłku fizycznego lub krwawienia z żylaków przełyku. Wymaga wówczas szczególnej uwagi, ponieważ nie ustalono dotychczas specyficznej dla niej terapii, a niektóre leki stosowane powszechnie w leczeniu niewydolności serca wpływają niekorzystnie na jej przebieg kliniczny. Wydaje się, że wszyscy pacjenci z rozpoznaną umiarkowaną i ciężką marskością wątroby już w momencie postawienia diagnozy mogą odnieść wymierne korzyści z badania przesiewowego w kierunku występowania kardiomiopatii wątrobowej.

Słowa kluczowe: kardiomiopatia wątrobowa, diagnostyka, leczenie

Folia Cardiologica 2016; 11, 3: 209-214

\section{Wstęp}

Kardiomiopatię wątrobową (CCM, cirrhotic cardiomyopathy) definiuje się jako zespół zaburzeń funkcji serca występujących u osób z nadciśnieniem wrotnym i marskością wątroby, w przypadku braku innej, znanej przyczyny choroby serca (choroba niedokrwienna serca, nadciśnienie tętnicze, wada serca) i niezależnie od spożycia alkoholu $[1,2]$.

Obecnie wiadomo, że rozpoznanie CCM niesie za sobą konkretne przesłanie praktyczne, ponieważ jej powstanie skutkuje zwiększeniem ryzyka ostrych powikłań kardiologicznych i zwiększeniem śmiertelności po ortotopowym przeszczepie wątroby lub po zabiegu wytworzenia przezszyjnego wewnątrzwątrobowego zespolenia wrotno-systemowego (TIPS, transjugular intrahepatic portosystemic shunt) stosowanym w leczeniu nadciśnienia wrotnego [3].

\section{Dysfunkcja skurczowa w przebiegu kardiomiopatii wątrobowej}

Niezdolność do wykonywania pracy obserwuje się dość często u chorych z marskością wątroby, zwłaszcza tych z wodobrzuszem, a uczucie ogólnego osłabienia sprawia, że rzadko mają oni okazję do większego wysiłku fizycznego. U większości chorych z marskością wątroby, nawet w okresie jej dekompensacji, funkcja skurczowa serca w spoczynku określana przy pomocy konwencjonalnej echokardiografii i rozpatrywana całościowo jest prawidłowa, ponieważ u takich chorych obserwuje się zwykle tachykardię ze zwiększoną pojemnością minutową, która następnie ulega obniżeniu wraz z postępem choroby. W spoczynku u chorych na CCM obserwuje się zwykle zwiększony wymiar lewego przedsionka, poszerzoną ścianę lewej komory serca, zmniejszoną

Adres do korespondencji: dr n. med. Adam R. Markowski, Oddział Chorób Wewnętrznych i Gastroenterologii, Samodzielny Szpital Miejski im. PCK, ul H. Sienkiewicza 79, 15-003 Białystok, tel.: 856648 512, faks: 856648 512, e-mail: markowski@szpitalpck.pl 
objętość końcoworozkurczową i końcowoskurczową lewej komory (LVEDV, left ventricular end-diastolic volume; LVESV, left ventricular end-systolic volume) i zmniejszoną frakcję wyrzutową lewej komory (LVEF, left ventricular ejection fraction) oraz wydłużony czas rozkurczu izowolumetrycznego (IVRT, isovolumic relaxation time).

Pomimo zachowanej globalnej funkcji mięśnia sercowego jako pompy, u chorych z marskością wątroby nawet w spoczynku mogą występować dyskretne zaburzenia kurczliwości regionalnej wykrywane przy pomocy nowoczesnych metod obrazowania. Jedną z nich, bardziej czułą od konwencjonalnej echokardiografii, jest tkankowa echokardiografia doplerowska (TDI, tissue doppler imaging), która pozwala obserwować odkształcanie miokardium w warunkach spoczynkowych, szczególnie z zastosowaniem technik ilościowych $[4,5]$. Technika poklatkowego śledzenia markerów akustycznych (STE, speckle tracking echocardiography) pozwala uzyskać bardziej powtarzalne wskaźniki deformacji mięśnia sercowego, określające skurczową i rozkurczową funkcję poszczególnych segmentów mięśnia sercowego, niezależnie od kąta padania wiązki ultradźwiękowej; odkształcenie podłużne (GLS, global longitudinal strain) jest wiarygodnym wskaźnikiem funkcji skurczowej lewej komory w przebiegu CCM, bardziej czułym i dokładnym niż pomiar frakcji wyrzutu oraz niezależnym od etiologii marskości wątroby i stanu klinicznego [6].

W ocenie czynnościowej znajduje zastosowanie również obrazowanie serca za pomocą rezonansu magnetycznego wykazujące większą czułość i specyficzność niż echokardiografia. Technika znakowania magnetycznego ścian serca ruchomą siatką, która odkształca się w skurczu (MR-MT, magnetic resonance-myocardial tagging), umożliwia uwidocznienie nawet niewielkich segmentów serca o nieprawidłowej ruchomości ścian i tym samym wczesne zidentyfikowanie obszarów hipokinezy lub akinezy [7].

Tomografia emisyjna pojedynczego fotonu bramkowana sygnałem EKG (ECG-G SPECT, electrocardiogram-gated single-photon emission computed tomography) umożliwia jednoczesne obrazowanie odcinkowych zaburzeń kurczliwości i upośledzonej perfuzji oraz pomiar EF i objętości lewej komory serca w poszczególnych fazach cyklu jego pracy; u chorych na CCM nawet w warunkach podstawowych obserwuje się dyskretne nieprawidłowości [8].

\section{Dysfunkcja rozkurczowa w przebiegu kardiomiopatii wątrobowej}

Patofizjologicznym podłożem dysfunkcji rozkurczowej u chorych z marskością wątroby jest zwiększona sztywność ścian i tym samym zmniejszona podatność rozkurczowa lewej komory, spowodowana prawdopodobnie jej włóknieniem, obrzękiem i niewielkim przerostem, co łącznie skutkuje zaburzeniami relaksacji [9]. U podstaw dysfunkcji rozkurczowej w przebiegu CCM leżą również zaburzenia czynnościowe, ponieważ zmniejszenie nasilenia dysfunkcji rozkurczowej odnotowano po paracentezie u pacjentów z wodobrzuszem [10].

Dysfunkcja rozkurczowa serca staje się istotnym problemem klinicznym w warunkach stresu hemodynamicznego, ponieważ sztywna i przerośnięta lewa komora nie jest w stanie sprostać zapotrzebowaniu w zakresie utrzymania adekwatnego ciśnienia tętniczego i pojemności minutowej [11]. W nagłych sytuacjach, takich jak na przykład krwawienie z żylaków przełyku, obserwuje się mniejszy przyrost frakcji wyrzutu i mniejszą częstość rytmu serca; wówczas niewydolność skurczowa może stać się objawowa. Takie zjawisko obserwuje się również w krótkim okresie po zabiegu TIPS; chorzy, u których nie stwierdza się poprawy funkcji rozkurczowej w okresie 28 dni po zabiegu, są obciążeni większą śmiertelnością [12]. Określany w trakcie konwencjonalnej echokardiografii wskaźnik E/A $\leq 1$ okazał się niezależnym czynnikiem predykcyjnym zgonu u takich chorych, prawdopodobnie zależnie od nasilenia zaburzeń hemodynamicznych w okresie okołozabiegowym [13]. Dlatego precyzyjna ocena serca w kierunku dysfunkcji rozkurczowej przed zabiegiem ma duże praktyczne znaczenie kliniczne.

Stopień nasilenia dysfunkcji rozkurczowej koreluje odwrotnie z czasem przeżycia, zależnie od stopnia nasilenia CCM, postępującej wraz z niewydolnością wątroby [2]. Podczas tkankowej echokardiografii dopplerowskiej można dodatkowo zakodować kolorem (CDMI, color Doppler myocardial imaging) prędkość ruchu miokardium, co umożliwia ocenę fragmentów mięśnia sercowego zależnie od ich chwilowej prędkości i pozwala ocenić synchronię ruchu tkanek. Prędkość propagacji fali napływu mitralnego jest niezależnym czynnikiem prognostycznym śmiertelności u chorych z marskością wątroby i zachowaną funkcją skurczową lewej komory serca [14].

\section{Dysfunkcja autonomiczna w przebiegu kardiomiopatii wątrobowej}

Częstym zjawiskiem u chorych z marskością wątroby jest uogólniona dysfunkcja autonomicznego układu nerwowego zaopatrującego układ sercowo-naczyniowy. Jej przejawem jest niewydolność chronotropowa, zwiększona aktywność współczulnego układu nerwowego oraz zmniejszona wrażliwość odruchu z baroreceptorów i obniżona zmienność rytmu serca [15].

Główną nieprawidłowością elektrofizjologiczną obserwowaną w EKG u chorych z marskością wątroby jest wydłużenie odstępu QT, powstałe prawdopodobnie jako rezultat defektu sercowych kanałów potasowych i wapniowych. Sytuacje kliniczne, w których występuje zwiększone pobudzenie współczulnego układu nerwowego, takie jak na przykład krwawienie z żylaków przełyku i hipotonia, powodują wydłużenie odstępu QT. To, czy jest on tylko czynnikiem 
prognostycznym, czy jest również czynnikiem wpływającym na zwiększoną śmiertelność chorych z marskością wątroby ze względu na swój arytmogenny potencjał, pozostaje do ustalenia. Zmienna częstość występowania wydłużonego odstępu QT u chorych z marskością wątroby może być skutkiem używania różnych metod wyliczania QTc. Wzór Bazetta jest stosowany powszechnie, ale jest też zależny od częstości rytmu serca, co u chorych z marskością wątroby może mieć istotne znaczenie, ze względu na występującą często tachykardię. W tym celu Zambruni i wsp. opracowali wzór specjalnie dedykowany chorym z marskością wątroby [16].

\section{Biomarkery użyteczne w diagnostyce kardiomiopatii wątrobowej}

Niektóre biomarkery mogą pomóc w wykryciu CCM na wczesnym etapie jej rozwoju. Zwiększone stężenie w surowicy peptydu natriuretycznego typu B jest jednym z nich i dodatkowo stanowi ważny czynnik predykcyjny wyższej śmiertelności [17]. U chorych z marskością wątroby, zwłaszcza w stadium dekompensacji, obserwuje się również zwiększone stężenie w surowicy wysokoczułej troponiny $\mathrm{T}$, które koreluje ze stopniem nasilenia marskości wątroby i jest znacznie wyższe w surowicy chorych w klasie C niż w klasie A. Wydaje się, że znaczenie prognostyczne ma także jeden z markerów stanu zapalnego, czyli rozpuszczalny receptor typu urokinazowego dla aktywatora plazminogenu [15].

Powszechnie akceptowane podstawowe kryteria diagnostyczne CCM są następujące [18]:

- zmniejszony wzrost pojemności minutowej w warunkach stresu hemodynamicznego;

- spoczynkowa EF < 55\%;

- E/A < 1,0 (skorygowany względem wieku);

- DT > $200 \mathrm{~ms}$;

- IVRT > 80 ms. Kryteria dodatkowe stanowią:

- nieprawidłowości elektrofizjologiczne;

- dysfunkcja chronotropowa;

- zaburzenia sprzężenia elektromechanicznego;

- wydłużony odstęp QTc;

- powiększony lewy przedsionek;

- zwiększona masa mięśnia sercowego;

- zwiększone stężenia BNP i pro-BNP;

- zwiększone stężenie troponiny I.

\section{Kliniczne znaczenie kardiomiopatii wątrobowej}

Kardiomiopatia wątrobowa wymaga różnicowania z innymi jednostkami chorobowymi o podobnym obrazie klinicznym, które można spotkać u pacjentów z marskością wątroby, na przykład kardiomiopatią restrykcyjną w przebiegu hemochromatozy, przerostem mięśnia lewej komory serca w przebiegu nadciśnienia tętniczego czy kardiomiopatią w przebiegu amyloidozy. Ponieważ w większości przypadków CCM ma przebieg subkliniczny, a jej objawy pojawiaja się dopiero w warunkach stresu hemodynamicznego, zwykle obserwuje się małe zainteresowanie klinicystów jej diagnozowaniem, zwłaszcza na etapie bezobjawowym. Również historia naturalna CCM jest przez to mniej poznana.

Brak dotychczas dowodów na korzyść z jakiejkolwiek specyficznej terapii CCM. Leczenie objawowej niewydolności serca w przebiegu CCM powinno przebiegać zgodnie z ogólnymi zasadami leczenia niewydolności serca u chorych bez marskości wątroby, włącznie z redukcją obciążenia wstępnego i zastosowaniem diuretyków. Jednak leki stosowane powszechnie w leczeniu niewydolności serca nie znajdują szerokiego zastosowania w leczeniu CCM.

$\mathrm{U}$ chorych ze zdekompensowaną marskością wątroby zwykle występuje hiperaldosteronizm, który ma istotny wpływ na nerkową retencję sodu i wody oraz jest główną przyczyną oporności na diuretyki pętlowe stosowane w monoterapii. W przypadku współistniejącego wodobrzusza, u chorych z marskością wątroby stosuje się powszechnie dietę niskosodową oraz spironolakton w celu osiągnięcia ujemnego bilansu sodowego, ponieważ to retencja sodu odgrywa kluczową rolę w powstaniu wodobrzusza. Terapia spironolaktonem dodatkowo może hamować wywołane działaniem aldosteronu włóknienie serca i w ten sposób zmniejszać grubość jego ściany i objętość końcoworozkurczową lewej komory; jednak udowodniono, że kuracja spironolaktonem nie poprawia trwale funkcji rozkurczowej serca i nie przynosi ewidentnej korzyści w leczeniu CCM [19]. Konieczne są dalsze badania kliniczne.

Redukcja obciążenia następczego nie jest dobrze tolerowana przez chorych z zaawansowaną marskością wątroby, u których występuje znaczna wazodylatacja naczyń, a ciśnienie tętnicze jest podtrzymywane między innymi przez podwyższone stężenie czynników wazokonstrykcyjnych, takich jak wazopresyna, angiotensyna i aldosteron. Dlatego leków z grupy inhibitorów enzymu konwertującego oraz antagonistów receptorów angiotensyny należy unikać lub stosować u chorych z marskością wątroby i wodobrzuszem ze szczególną ostrożnością i pod rygorem skrupulatnego nadzoru ciśnienia tętniczego oraz funkcji nerek [20]. Jedynie małe dawki inhibitorów enzymu konwertującego (losartan 12,5-25 mg/d.) wydają się wykazywać korzystny efekt obniżający ciśnienie wrotne (porównywalny z zastosowaniem propranololu 40-80 mg/d.) i jednocześnie akceptowalny profil bezpieczeństwa u chorych z marskością wątroby [21].

Biorąc pod uwagę defekt funkcji przekazywania sygnałów przy udziale receptorów beta-adrenergicznych u chorych z marskością wątroby, zastosowanie antagonistów receptorów beta nie jest szczególnie dobrą opcją. Jednak wykazano, że włączenie do terapii małej dawki $(6,25-12,5 \mathrm{mg} / \mathrm{d}$.) karwedilolu jest nie tylko dobrze tolerowane, ale i bardziej 
efektywne w obniżaniu ciśnienia wrotnego niż kuracja propranololem (80-100 mg/d.), przy podobnym wpływie na systemowe ciśnienie tętnicze i częstość rytmu serca; zwiększenie dawki karwedilolu nie przynosi większych korzyści, jednocześnie narażając chorych na wystąpienie niekorzystnych działań ubocznych, to jest hipotensji i bradykardii [22]. Wiadomo, że podanie nieselektywnych antagonistów receptorów beta-adrenergicznych może redukować ciśnienie wrotne poniżej $12 \mathrm{~mm}$ Hg i tym samym zmniejszać częstość występowania krwawienia z żylaków przełyku i gastropatii wrotnej, dodatkowo skraca wydłużony odstęp QT i redukuje objawy zespołu hiperdynamicznego u chorych z marskością wątroby oraz zmniejsza częstość występowania poważnego powikłania marskości wątroby, jakim jest spontaniczne bakteryjne zapalenie otrzewnej. Nieselektywnych antagonistów receptorów beta uznaje się powszechnie za „aspirynę hepatologów”. Jednak w prospektywnym badaniu klinicznym wykazano, że kardiodepresyjny efekt działania propranololu może skracać okres przeżycia u chorych z marskością wątroby i nawracającym wodobrzuszem oraz zwiększać częstość występowania niewydolności krążenia indukowanej paracentezą [23, 24]. W innym badaniu ujawniono, że włączenie nieselektywnych antagonistów receptorów beta u chorych z marskością wątroby i już obecnym spontanicznym bakteryjnym zapaleniem otrzewnej zwiększa odsetek chorych niewydolnych hemodynamicznie i ryzyko powstania zespołu wątrobowo-nerkowego [25]; brak dotychczas takich danych dla karwedilolu. Powyższe ryzyko i korzyści płynące z włączenia do terapii leków blokujących receptory beta-adrenergiczne powinny być oszacowane skrupulatnie u wszystkich pacjentów z marskością wątroby. Aktualnie nie mogą być one rekomendowane w rutynowym leczeniu CCM u osób z zaawansowaną marskością wątroby i nawracającym wodobrzuszem lub spontanicznym bakteryjnym zapaleniem otrzewnej, a rozpoczęta wcześniej terapia powinna zostać przerwana, zwłaszcza u chorych z postępującą hipotensją i pogarszającą się funkcją nerek [26]. U takich chorych zamiast profilaktyki farmakologicznej krwawienia z żylaków przełyku należy rozważyć endoskopowe opaskowanie żylaków.

Szacowana częstość występowania zagrażających życiu arytmii u chorych z marskością wątroby jest prawdopodobnie zaniżona, ponieważ zwykle nie prowadzi się u nich stałego monitorowania EKG, nawet gdy pojawią się powikłania. Prawdopodobne jest, że w trudnych warunkach klinicznych, takich jak na przykład krwawienie z przewodu pokarmowego, które prowadzi do nagłego zwiększenia aktywności układu współczulnego i uwolnienia cytokin, zaburzenia repolaryzacji komór mogą ujawnić swój szkodliwy potencjał. Wydłużony odstęp QT zależy od stopnia dysfunkcji wątroby i nasilenia nadciśnienia wrotnego oraz stężenia krążącej we krwi noradrenaliny, a obecność wydłużonego odstępu QT i jednocześnie prawidłowej dyspersji odstępu QT u chorych z marskością wątroby sugeruje opóźnioną repolaryzację kardiomiocytów [18]. Udowodniono bezpośrednią korelację pomiędzy długością odstępu QT i czasem trwania skurczu serca, prawdopodobnie zależną od nieprawidłowej funkcji kanałów potasowych. Dodatkowo zwiększone stężenie cytokin uwalnianych w trakcie infekcji czy krwawienia z żylaków przełyku może niekorzystnie wpływać na pobudliwość i kurczliwość kardiomiocytów [27].

Należy zdawać sobie sprawę, że leki stosowane u chorych z marskością wątroby, na przykład niektóre antybiotyki z grupy chinolonów, wydłużają dodatkowo odstęp QT i sprzyjają powstaniu arytmii komorowych. Ocena odstępu QT u takich chorych powinna więc być okresowo przeprowadzana. Rzeczywista częstość występowania CCM jest nieznana i może zostać orientacyjnie określona jedynie na podstawie znanej częstości występowania u chorych z marskością wątroby wydłużenia odstępu QT, uznawanego powszechnie za najwcześniejszy objaw CCM; częstość tę szacuje się na 25\%, 51\% i 60\% u chorych z marskością wątroby odpowiednio w klasie A, B i C według skali Childa-Turcotte'a-Pugha [28].

Ostatecznym rozwiązaniem i jedyną metodą o udowodnionej skuteczności w terapii CCM jest ortotopowy przeszczep wątroby, który nie tylko skraca wydłużony QTc, ale powoduje też ustąpienie dysfunkcji rozkurczowej w okresie 6-12 miesięcy po zabiegu [29]; ciężka dysfunkcja rozkurczowa w przebiegu CCM jest czynnikiem ryzyka powstania niewydolności serca po przeszczepie, a niekiedy również stanowi przyczynek do rozważenia przeszczepu serca [30].

Biorąc to wszystko pod uwage, wskazane jest wykonywanie badania przesiewowego u chorych z marskością wątroby w kierunku CCM. Manov i wsp. sugerują zastosowanie kilku prostych kryteriów klinicznych włączenia do takiego badania:

- stężenie w surowicy czynnika natriuretycznego typu B: BNP > $350 \mathrm{ng} / \mathrm{l}$;

- stężenie w surowicy endoteliny: ET-1 > 19,0 pg/ml;

- stężenie w surowicy aldosteronu > 512 ng/ml;

- komorowe zaburzenia rytmu serca co najmniej w II klasie według Lowna;

- odstęp QT > 400 ms;

- prędkość przepływu krwi w żyle wrotnej < 5,8 m/s;

- obecność wodobrzusza;

- obecność żylaków przełyku co najmniej II ${ }^{\circ}$;

- szerokość żyły wrotnej > $13 \mathrm{~mm}$;

- rozmiar śledziony $>14 \mathrm{~cm}$ [31].

\section{Wnioski}

Kardiomiopatia wątrobowa jest nie w pełni jeszcze poznaną jednostką chorobową. Wydaje się, że wszyscy pacjenci z zaawansowaną marskością wątroby powinni być badani przesiewowo w kierunku CCM, z kilku powodów. Po pierwsze, bezobjawowa dysfunkcja skurczowa i rozkurczowa może poprzedzać występowanie objawowej niewydolności 
serca i stwierdzenie tych nieprawidłowości może prawidłowo ukierunkować postępowanie diagnostyczno-lecznicze; w pierwszym okresie marskości wątroby jest to trudne, ponieważ zespół krążenia hiperkinetycznego może maskować początkowe objawy CCM, tym samym utrudniając postawienie rozpoznania.

Po drugie, prewencja i leczenie niektórych powikłań marskości wątroby (np. zespołu wątrobowo-nerkowego) polega na podawaniu leków o działaniu wazokonstrykcyjnym, co w obu przypadkach może doprowadzić do niekorzystnych następstw; wcześniejsze rozpoznanie CCM może przed nimi ustrzec.
Po trzecie, w krótkim okresie po przeszczepieniu wątroby lub po zabiegu TIPS u chorych z CCM obserwuje się dekompensację układu krążenia spowodowaną nagłym przemieszczeniem większej objętości krwi z krążenia wrotnego do systemowego, co skutkuje większą śmiertelnością; wiedza o występowaniu CCM u takich chorych może ustrzec przed ich nadmiernym obciążeniem objętościowym, poprawiając rokowanie.

\section{Konflikt interesów}

Autorzy nie zgłaszają konfliktu interesów.

\section{Abstract}

Cirrhotic cardiomyopathy is a clinical syndrome characterized by cardiac function disturbances with a systolic and diastolic dysfunction, as well electromechanical abnormalities, occurring in patients with liver cirrhosis, in the absence of another known cause of heart disease, regardless of alcohol consumption. The course of cirrhotic cardiomyopathy is usually subclinical, and its symptoms often manifest only in conditions of hemodynamic stress, such as excessive physical exercise or bleeding from esophageal varices. Then it requires the special attention, because there is no established specific therapy of cirrhotic cardiomyopathy, and some drugs commonly used in the treatment of heart failure adversely affect its course.

It seems that all patients with established moderate and severe liver cirrhosis, at the time of diagnosis, may benefit from screening for the presence of cirrhotic cardiomyopathy.

Key words: cirrhotic cardiomyopathy, diagnosis, treatment

Folia Cardiologica 2016; 11, 3: 209-214

\section{Piśmiennictwo}

1. Møller S., Henriksen J.H. Cardiovascular complications of cirrhosis. Gut 2008; 57: 268-278.

2. Ruiz-del-Arbol L., Achecar L., Serradilla R i wsp. Diastolic dysfunction is a predictor of poor outcomes in patients with cirrhosis, portal hypertension, and a normal creatinine. Hepatology 2013; 58: 1732-1741.

3. Fouad T.R., Abdel-Razek W.M., Burak K.W. i wsp. Prediction of cardiac complications after liver transplantation. Transplantation 2009; 87: 763-770.

4. Kazankov K., Holland-Fischer P., Andersen N.H. i wsp. Resting myocardial dysfunction in cirrhosis quantified by tissue Doppler imaging. Liver Int. 2011; 31: 534-540.

5. 5. Sampaio F., Pimenta J., Bettencourt N. i wsp. Systolic and diastolic dysfunction in cirrhosis: a tissue-Doppler and speckle tracking echocardiography study. Liver Int. 2013; 33: 1158-1165.

6. Galderisi M., Lomoriello V.S., Santoro A. i wsp. Differences of myocardial systolic deformation and correlates of diastolic function in competitive rowers and young hypertensives: a speckle-tracking echocardiography study. J. Am. Soc. Echocardiogr. 2012; 23: 1190-1198.

7. Kovács A., Schepke M., Heller J. i wsp. Short-term effects of transjugular intrahepatic shunt on cardiac function assessed by cardiac MRI: preliminary results. Cardiovasc. Intervent. Radiol. 2010; 33: 290-296.
8. Krag A., Bendtsen F., Mortensen C. i wsp. Effects of a single terlipressin administration on cardiac function and perfusion in cirrhosis. Eur. J. Gastroenterol. Hepatol. 2010; 22: 1085-1092.

9. Pozzi M., Carugo S., Boari G. i wsp. Evidence of functional and structural cardiac abnormalities in cirrhotic patients with and without ascites. Hepatology 1997; 26: 1131-1137.

10. Sembiring J., Karo-Karo T., Latif L. i wsp. The role of ascitic paracentesis in liver cirrhosis in improving the function and structure of the heart. Indon. J. Gastr. Hepatol. Dig. Endosc. 2003; 4: 1-5.

11. Wong F., Girgrah N., Graba J. i wsp. The cardiac response to exercise in cirrhosis. Gut 2001; 49: 268-275.

12. Cazzaniga M., Salerno F., Pagnozzi G. i wsp. Diastolic dysfunction is associated with poor survival in patients with cirrhosis with transjugular intrahepatic portosystemic shunt. Gut 2007; 56: 869-875.

13. Rabie R.N., Cazzaniga M., Salerno F., Wong F. The use of E/A ratio as a predictor of outcome In cirrhotic patients treated with transjugular intrahepatic portosystemic shunt. Am. J. Gastroenterol. 2009; 104: 2458-2466.

14. Nguyen P.K., Schnittger I., Heidenreich P.A. A comparison of echocardiographic measures of diastolic function for predicting all-cause mortality in a predominantly male population. Am. Heart J. 2011; 161: 530-537. 
15. Wiese S., Mortensen C., Gøtze J.P. i wsp. Cardiac and proinflammatory markers predict prognosis in cirrhosis. Liver Int. 2014; 34: e19-e30.

16. Zambruni A., Di Micoli A., Lubisco A. i wsp. QT interval correction in patients with cirrhosis. J. Cardiovasc. Electrophysiol. 2007; 18: 77-82.

17. Pimenta J., Paulo C., Gomes A. i wsp. B-type natriuretic peptide is related to cardiac function and prognosis in hospitalized patients with decompensated cirrhosis. Liver Int. 2010; 30: 1059-1066.

18. Møller S., Hove J.D., Dixen U., Bendtsen F. New insights into cirrhotic cardiomyopathy. Int. J. Cardiol. 2013; 167: 1101-1108.

19. Pozzi M., Grassi G., Ratti L. i wsp. Cardiac, neuroadrenergic, and portal hemodynamic effects of prolonged aldosterone blockade in postviral child A cirrhosis. Am. J. Gastroenterol. 2005; 100: 1110-1116.

20. Gines P., Angeli P., Lenz K. i wsp. EASL clinical practice guideline on the management of ascites, spontaneous bacterial peritonitis, and hepatorenal syndrome. J. Hepatol. 2010; 53: 397-417.

21. Agasti A.K., Mahajan A.U., Phadke A.Y. i wsp. Comparative randomized study on efficacy of losartan versus propranolol in lowering portal pressure in decompensated chronic liver disease. J. Dig. Dis. 2013; 14: 266-271.

22. Reiberger T., Ulbrich G., Ferlitsch A. i wsp. Carvedilol for primary prophylaxis of variceal bleeding in cirrhotic patients with haemodynamic non-response to propranolol. Gut 2013; 62: 1634-1641.
23. Serste T., Melot C., Francoz C. i wsp. Deleterious effects of beta-blockers on survival in patients with cirrhosis and refractory ascites. Hepatology 2010; 52: 1017-1022.

24. Serste T., Francoz C., Durand F. i wsp. Beta-blockers cause paracentesis-induced circulatory dysfunction in patients with cirrhosis and refractory ascites: a cross-over study. J. Hepatol. 2011; 55: 794-799.

25. Mandorfer M., Bota S., Schwabl P. i wsp. Nonselective $\beta$ blockers increase risk for hepatorenal syndrome and death in patients with cirrhosis and spontaneous bacterial peritonitis. Gastroenterology 2014; 146: 1680-1690.

26. Ge P.S., Runyon B.A. The changing role of beta-blocker therapy in patients with cirrhosis. J. Hepatol. 2014; 60: 643-653.

27. Bernardi M., Maggioli C., Dibra V., Zaccherini G. QT interval prolongation in liver cirrhosis: innocent bystander or serious threat? Expert Rev. Gastroenterol. Hepatol. 2012; 6: 57-66.

28. Zardi E.M., Zardi D.M., Chin D. i wsp. Cirrhotic cardiomyopathy in the pre- and post-liver transplantation phase. J Cardiol. 2016; 67: 125-130.

29. Torregrosa M., Aguadé S., Dos L. Cardiac alterations in cirrhosis: reversibility after liver transplantation. J. Hepatol. 2005; 42: 68-74.

30. Hsu R.B., Chang C.I., Lin F.Y. i wsp. Heart transplantation in patients with liver cirrhosis. Eur. J. Cardiothorac. Surg. 2008; 34: 307-312.

31. Manov E.I., Runev N.M., Donova T.I., Tchernev K.G. Can the development of cardiac dysfunction in patients with liver cirrhosis and portal hypertension be predicted? Int. J. Cardiol. 2013; 168: 1528-1530. 